\title{
Study of the development trajectory of the status indicator in employment in the context of digital transformation
}

\author{
Elena Avdeeva ${ }^{1}$, Tatiana Averina ${ }^{1, *}$, and Natalia Butyrina $^{1}$ \\ ${ }^{1}$ Voronezh State Technical University, Moscow Avenue, 14, Voronezh, 394026, Russia
}

\begin{abstract}
Changes in employment status and rising unemployment are global and driven by rapid technological progress. The coronavirus pandemic also played a huge role, increasing the unemployment rate by 2 $4 \%$ in different economies. The most declining industries are arts, culture and recreation; spheres of education, law and social, communal and state services; trade. Today, the fragmentation of employment up to selfemployment and the spread of various forms of precarious work are clearly visible, and there is an inverse relationship between the share of selfemployed workers and the GDP of their countries: in 2018, Burundi had the highest level of self-employment in the world - almost 95\%. Arab countries posted the lowest self-employment rates at $1.7 \%$. The emergence of new professions and employment profiles opens up a number of opportunities for the unemployed and the self-employed.
\end{abstract}

\section{Introduction}

Technological advances are leading to massive automation and irreversible shifts in the structure of employment, which pose significant challenges to the labour market and policymakers in education and employment. Thanks to social, economic and technological development, new forms of employment are emerging that differ in many respects from traditional standard or precarious work. Some are transforming the relationship between employer and employee, some are changing work organization and working hours, and some are both.

The purpose of the study was to identify the main trends in the status of employment based on the analysis and interpretation of statistical information from Rosstat, statistics from international organizations and foreign countries.

\section{Materials and Methods}

The methodological basis of the study was a system analysis and methods of comparative analysis, statistical methods, expert assessments, the method of graphic images. A number of works devoted to the issues of changing the status of employment have been analyzed [1-3].

\footnotetext{
*Corresponding author: ta_averina@mail.ru
} 
Emerging technologies are making it possible to divide the workflow into smaller operations within global digital manufacturing. The development of the service sector is also reflected in the growing fragmentation of employment up to self-employment. Work tasks are already more fragmented; more and more workers perform non-standard operations, both at the main place of employment, and as an additional part-time job [4]. There are career differences between the self-employed and the traditionally employed [5]. The concept of hybrid self-employed has appeared. These authors include individual self-employed persons with additional income from employment. These, according to the authors of the work, are self-employed, with the help of employment seeking to increase their income; or employees who create their own business [6].

By testing the structural model of self-employed individuals' engagement and growth, and examining the two types of exit intentions, Beitell concluded that work-family conflict (demand) and work-family synergy (resource) are most closely related to tension and engagement. Stress was positively associated with both growth and exit intentions, while engagement was inversely related to exit intentions but positively associated with growth [7].

\section{Results}

Global unemployment has been roughly stable for the past nine years, but slowing global economic growth means that as the global workforce grows, not enough new jobs are being created. In 2020, unemployment was projected to increase by about 2.5 million, but due to the coronavirus pandemic only in the United States, 10 million people lost their jobs during the two-week period at the end of March 2020. In September 2020, the national unemployment rate in the United States was about 12.58 million unemployed. [8]

World Employment and Social Outlook: Trends 2020 (WESO) shows that in addition to the global unemployment rate of 188 million, 165 million people are underpaid, and 120 million have either given up actively looking for work or do not have access to the labour market through other reasons. In total, more than 470 million people worldwide are affected [9]. The labour market situation has become more tense due to the pandemic (table 1).

Table 1. Unemployment rate in the largest economies in the world

\begin{tabular}{|l|c|c|}
\hline Country & $\begin{array}{l}\text { Unemployment rate at } \\
\text { the end of } 2019, \%\end{array}$ & $\begin{array}{l}\text { Unemployment rate for } \\
\text { the third quarter of } \\
2020, \%\end{array}$ \\
\hline Japan & 2.4 & 2.8 \\
\hline India & 3.5 & 5.4 \\
\hline Germany & 3.6 & 4.4 \\
\hline United Kingdom & 3.9 & 4.5 \\
\hline USA & 4.1 & 7.9 \\
\hline China & 4.8 & 3.8 \\
\hline Canada & 5.9 & 10.2 \\
\hline Russia & 4.6 & 6.17 \\
\hline France & 8.6 & 7.1 \\
\hline Italy & 10.4 & 9.7 \\
\hline Brazil & 11.6 & 13.8 \\
\hline
\end{tabular}

https://www.ceicdata.com/en/indicator/japan/unemployment-rate

Low unemployment does not mean that a country's economy is particularly strong. For example, in Myanmar in 2019, the unemployment rate was only $0.8 \%$, but according to the World Bank, its GDP per capita was \$1,408. In 2019, the unemployment rate in Niger was 
$0.4 \%$, but its GDP per capita was $\$ 555$, making it the poorest country on the list. Cambodia employed $99.7 \%$ of the workforce in 2019. In 2019, GDP per capita was US \$1,643, which is about US $\$ 4.50$ per day [10]. These countries have low unemployment rates, largely because their economies rely heavily on subsistence agriculture, which is labour intensive but seasonal. Underemployment is still included in employment indicators [11].

Employment status trends are showing negative dynamics. For example, an analysis of the state of employment in the Russian economy showed that the number of workers aged 15 and over in May 2020 amounted to 74.5 million people, of which 70.1 million were classified as employed in economic activity and 4.5 million people - as unemployed, meeting the ILO criteria, i.e. did not have a job or profitable occupation, were looking for a job and were ready to start it in the surveyed week (Figure 1). We see the negative consequences of the pandemic - 2.4 million people were left without work [12]. When looking for a job, 73.6\% will turn to friends and relatives and $53.7 \%$ will turn to the media and the Internet.

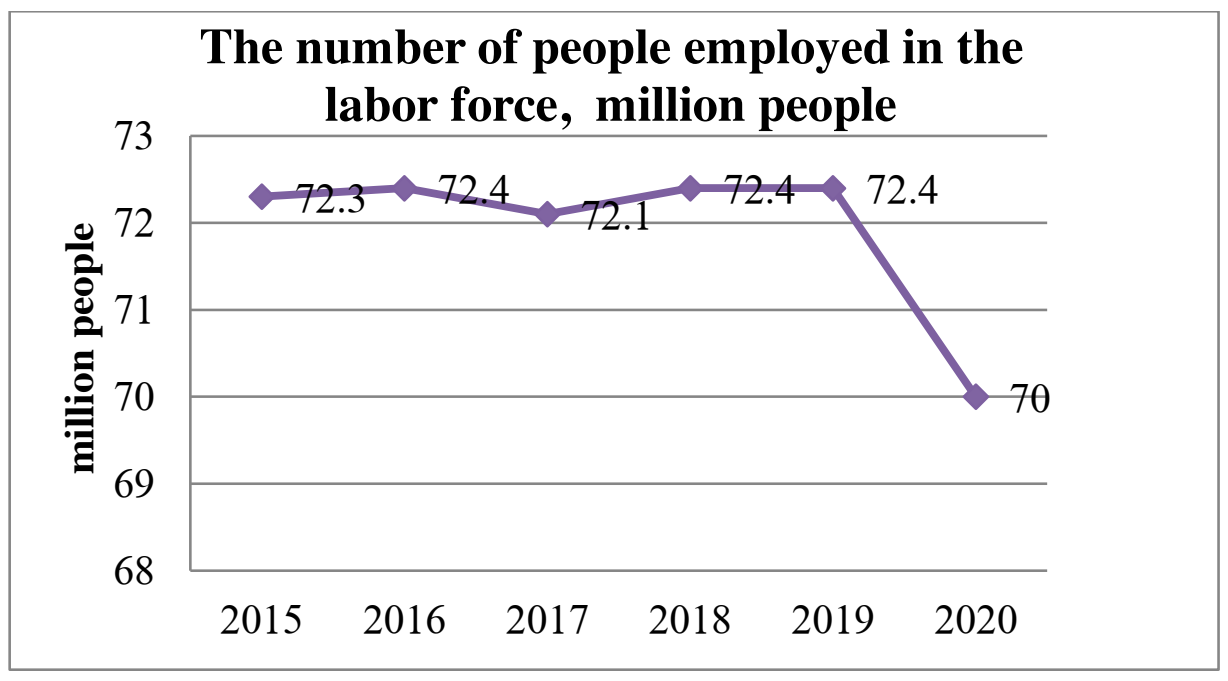

Fig. 1. Dynamics of the employed in the Russian economy. https://rosstat.gov.ru/bgd/free/B04_03/IssWWW.exe/Stg/d05/76.htm

The pandemic has fundamentally changed labour market trends. This was primarily reflected in a sharp increase in the number of unemployed. Among the Russian unemployed aged 15 and over, the share of women in July 2020 amounted to $47.4 \%$, urban residents $-71.2 \%$, youth from 15 to 25 years old - $20.5 \%$, persons with no work experience $-21.9 \%$. The unemployment rate among rural residents $(7.9 \%)$ exceeds the unemployment rate among urban residents $(5.8 \%)$. The male unemployment rate $(6.5 \%)$ exceeds the female unemployment rate $(6.2 \%)$. Also, the unemployment rate in July 2020 compared to the second quarter of 2020 increased in most age groups [12].

Now let's look at current employment trends: change in the status indicator - selfemployed. Nearly half a billion people work fewer hours of paid hours than they would like or lack adequate access to paid work, according to a new report by the International Labour Organization (ILO). In addition, the status of individual unemployment increases the monthly probability of becoming self-employed, according to Li Yu and Mukoyama T., by about 0.9 percentage points, and this effect is almost constant throughout the business cycle [13]. High rates of transition to self-employment during recessions will not necessarily lead to economic recovery and a new boom due to entrepreneurial innovation [14]. Self-employment is also more risky during a recession because the option to return to paid work in the event of a business failure is more difficult. 
The disaggregation of employment information by employment status provides a statistical basis for describing the behavior and working conditions of workers, as well as for defining the socioeconomic group of an individual. A high proportion of hired workers in a country may mean faster economic development. If the proportion of self-employed workers (self-employed without employees) is significant, this may indicate a large agricultural sector and low growth in the formal economy [15]. In labour law, a person's employment status helps define the rights of employees and the responsibilities of their employer.

The statistical concept and methodology used by the ILO is as follows. The employment status indicator distinguishes between two categories of total employment. These are salaried (paid workers) and self-employed workers. The self-employed group is broken down into subcategories: self-employed workers with hired workers (employers), self-employed workers without hired workers (self-employed workers), members of production cooperatives, and workers in family businesses (also known as unpaid family workers). Comparability of data between countries is inconsistent by accounting for differences in data source, coverage, methodology, and other country-specific factors.

For example, in the Russian economy there are no unequivocal pros and cons of selfemployed or individual entrepreneurs (IE). Self-employment is more suitable for those who can work independently without hiring employees and have an annual income of up to 2.4 million rubles. So, it is beneficial to be self-employed, for example, builders and loaders. You do not have to pay regular contributions, as an individual entrepreneur does. The tax is charged only on actual earnings, that is, when there are no orders, you do not have to pay anything. In addition, the self-employed regime will be a godsend for those who want to rent out an apartment. This can be done officially by deducting only $4 \%$ or $6 \%$. If you have a main job, and renting an apartment is an additional income, you can be self-employed and work under an employment contract. Plus, the employer will pay all the necessary contributions. Registration of an individual entrepreneur is necessary for those who plan to hire employees or engage in trade [16].

The current dynamics of self-employment is influenced by global trends towards lower demand for labour in agriculture and deindustrialization. These processes, as evidenced by the statistics of the European market [9], lead to an increase in employment in the tertiary sector, to which today belong from 75 to $85 \%$ of the total labour force, while in the middle of the twentieth century it accounted for only 30 to $45 \%$ of the labour force. Research contextualization involves the recognition of the fact that the development of the service sector in general and its digitalization in particular contribute to the emergence of the smallest forms (units) of entrepreneurship with an owner and a single employee in one person [17]. The latter group includes many freelancers - self-employed, not included in official statistics. The share of individual self-employed in their total number in the EU countries is very large and in none of them falls below $50 \%$ with an average value of $70 \%$.

Analyzing the global state of self-employment, it becomes clear that in fact there is an inverse correlation between the share of self-employed workers and the GDP of their countries. According to the International Labour Organization (ILO), in high-income countries, on average, only $12.4 \%$ of workers are self-employed, while in low-income countries this figure rises to $81.9 \%$. This is an indicator of the prevalence of subsistence farming and people working without pay for family businesses.

In 2018, Burundi had the highest self-employment rate in the world at almost 95 percent. Arab countries have posted the lowest self-employment rates. 3.5 percent of workers were self-paid in the United Arab Emirates in 2018. In Qatar and Kuwait, the numbers were even lower at 1.7 percent and 0.4 percent, respectively. In Russia, this is also a very low indicator - 5.9 percent (Table 2, Figure 2) [18].

Table 2 World Development Indicators: Decent Work and Productive Employment 


\begin{tabular}{|c|c|c|c|c|c|c|}
\hline \multirow[t]{3}{*}{ Country } & \multirow{2}{*}{\multicolumn{2}{|c|}{$\begin{array}{l}\text { Contributing family } \\
\text { workers and workers } \\
\text { with their own } \\
\text { account, men } \\
\% \text { of male } \\
\text { employment }\end{array}$}} & \multirow{2}{*}{\multicolumn{2}{|c|}{$\begin{array}{l}\text { Contributing family } \\
\text { workers and workers } \\
\text { with their own } \\
\text { account, women } \\
\% \text { of female } \\
\text { employment }\end{array}$}} & \multicolumn{2}{|c|}{$\begin{array}{l}\text { GDP per employed } \\
\text { person }\end{array}$} \\
\hline & & & & & $\%$ & owth \\
\hline & 2000 & 2018 & 2000 & 2018 & $2000-02$ & $2015-18$ \\
\hline Afghanistan & 90.6 & 77.1 & 98.3 & 90.1 & .. & -1.9 \\
\hline Ethiopia & 87.7 & 83.6 & 91.9 & 89.3 & 1.3 & 5.0 \\
\hline India & 81.4 & 74.1 & 90.5 & 76.3 & 1.8 & 6.0 \\
\hline Cameroon & 67.8 & 65.1 & 90.5 & 83.5 & 0.9 & 1.0 \\
\hline Bangladesh & 62.0 & 50.6 & 81.0 & 67.6 & 2.2 & 4.0 \\
\hline China & 55.2 & 42.8 & 67.5 & 49.2 & 8.2 & 6.6 \\
\hline Azerbaijan & 47.8 & 48.2 & 65.6 & 63.3 & 6.3 & -2.0 \\
\hline World & 50.3 & 44.1 & 55.2 & 45.5 & 1.3 & 2.3 \\
\hline $\begin{array}{l}\text { Dominican } \\
\text { Republic }\end{array}$ & 45.6 & 48.0 & 28.0 & 28.5 & 2.1 & 3.5 \\
\hline Turkey & 34.6 & 24.9 & 57.6 & 33.2 & 0.6 & 1.4 \\
\hline Greece & 33.3 & 27.4 & 35.2 & 23.7 & 3.3 & -1.2 \\
\hline Argentina & 24.4 & 22.8 & 20.6 & 20.0 & -6.1 & -2.1 \\
\hline Poland & 24.4 & 18.6 & 22.3 & 13.3 & 3.6 & 2.9 \\
\hline Portugal & 18.9 & 14.2 & 21.0 & 9.3 & -0.1 & 0.3 \\
\hline Australia & 14.9 & 12.8 & 9.2 & 8.1 & 1.2 & 0.7 \\
\hline Ukraine & 15.6 & 16.7 & 20.2 & 13.0 & 7.5 & 3.4 \\
\hline Canada & 11.9 & 11.9 & 9.1 & 9.4 & 0.6 & 0.5 \\
\hline Finland & 11.5 & 11.7 & 6.6 & 7.4 & 1.0 & 1.1 \\
\hline Japan & 11.5 & 8.7 & 17.1 & 8.0 & 1.0 & -0.3 \\
\hline Austria & 7.8 & 7.9 & 9.4 & 6.9 & 0.6 & 1.0 \\
\hline Czech & 13.2 & 16.2 & 7.7 & 10.8 & 1.5 & 1.5 \\
\hline France & 7.8 & 8.6 & 6.2 & 6.2 & 0.0 & 1.0 \\
\hline North America & 5.4 & 5.1 & 4.3 & 4.0 & 1.6 & 0.8 \\
\hline Belarus & 4.9 & 4.4 & 2.1 & 2.2 & 3.3 & 0.7 \\
\hline Russia & 10.3 & 5.9 & 9.6 & 4.8 & 3.5 & 1.8 \\
\hline Germany & 6.3 & 6.2 & 5.2 & 5.0 & 0.8 & 0.9 \\
\hline $\begin{array}{l}\text { United Arab } \\
\text { Emirates }\end{array}$ & 1.7 & 0.7 & 0.5 & 2.3 & -5.4 & 1.5 \\
\hline
\end{tabular}




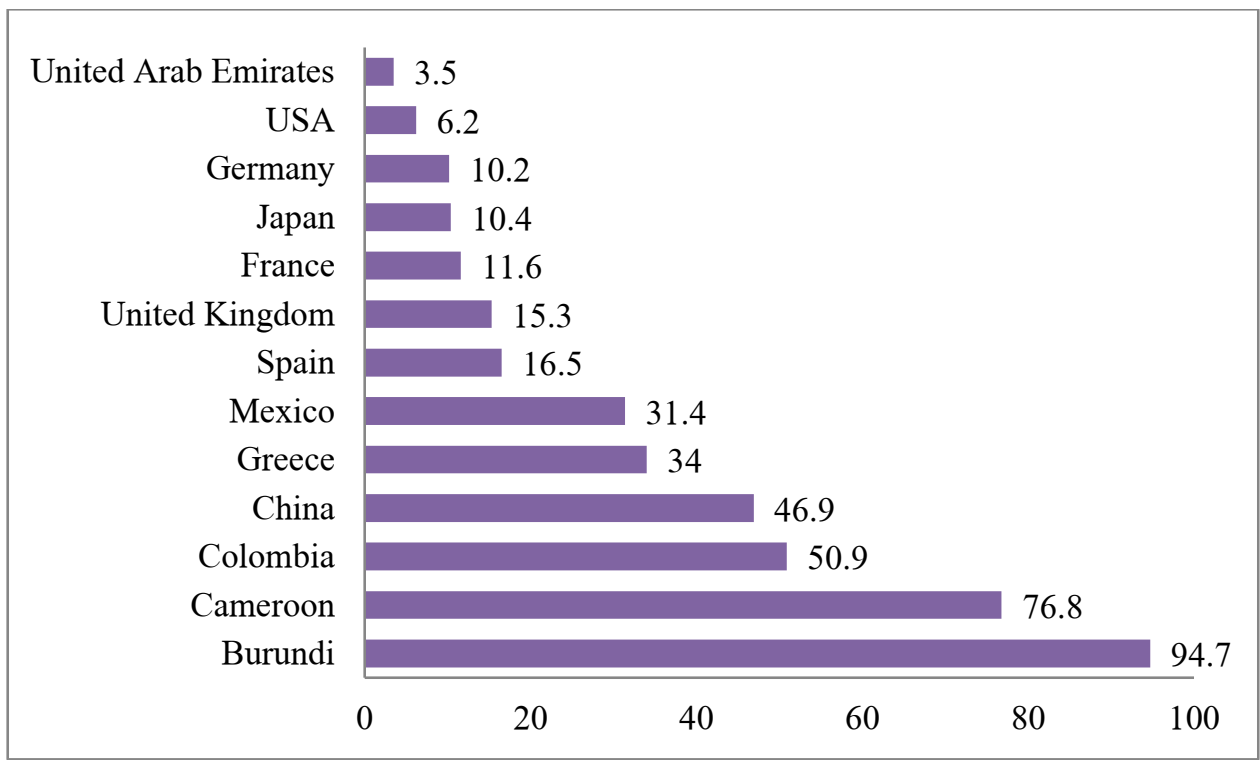

Fig. 2. Global trends in self-employment. The share of self-employed workers in 2018,\%. https://www.netigate.net/articles/employee-engagement/tips-for-working-from-home-productively

According to Eurostat's definition, economically dependent self-employed have been defined as self-employed who have worked in the last 12 months for only one client or for a dominant client, and this client has defined his working hours.

The largest share of self-employed persons without employees was observed in Slovakia (12.8\%), followed by Cyprus (8.9\%). Conversely, the rate of self-employed persons registered by Greece, Bulgaria, Estonia, Croatia, Latvia, Lithuania, Luxembourg and Malta was close to zero [18].

Independent self-employed persons mainly worked in the rural, forestry and fishing sectors, as well as in the wholesale and retail trade $(19.2 \%$ and $13.9 \%$ of the number of independent self-employed, respectively). On the other hand, dependent self-employed workers were mainly present in the construction sector and in the health and social work sectors (16.8\% and $11.1 \%$ of dependent self-employed, respectively). Professional, scientific and technical activities include a high proportion of both dependent and independent selfemployed persons: in fact, $9.8 \%$ and $13.0 \%$ of dependent and independent self-employed, respectively, worked in this sector of the economy [18]. On the other hand, self-employed dependents are rarely found in the following four sectors: room and board, finance and insurance, real estate, and households as employers.

Self-employed persons frequently reported the following occupations: craft and related trades workers $(14.9 \%)$, technicians and associates $(14.2 \%)$, service and trade workers $(13.8 \%)$, primary trades (9\%). 1 in 2 persons is very satisfied with his current job. They also reported several reasons for running their own business: a suitable opportunity $(22.7 \%)$, continuing a family business $(15.8 \%)$, regular local practices $(14.8 \%)$, flexible working hours $(11.2 \%)$, no job was found as an employee $(10.8 \%)$ and at the request of a former employer (1.9\%). In fifteen EU member states, "suitable opportunity" was the most frequently cited reason for becoming self-employed. The largest share of self-employed people who reported this reason was observed in Bulgaria (42.1\%), followed by Italy (39.0\%), Hungary $(35.9 \%)$ and Malta (33.3\%). Poland is the country where the share of self-employed people who noted that they are continuing a family business is the highest $(26.6 \%)$, followed by Slovenia $(25.5 \%)$, Austria and Greece (25.3\% each). The lack of employment as an employee is also 
a significant reason: $38.3 \%$ cited this reason in Romania, $25.3 \%$ in Cyprus and $22.7 \%$ in Croatia. A large proportion of the self-employed started their own business, because it was a common practice in the field: this proportion reached $28.2 \%$ in the Czech Republic, $27.6 \%$ in Belgium and 25.8\% in Slovakia [19-21].

The orientation towards the self-employed shows that the economically dependent selfemployed especially want to work as employees (32.6\%). The corresponding percentage for the self-employed without hired workers is $17.4 \%$, and for the self-employed with hired workers $-10.5 \%$. These results indicate that there is a strong relationship between individual status and willingness to change.

The total number of self-employed, according to the Federal Tax Service of Russia, reached 1 million Russians in June 2020, and 3.5 thousand people are registered every day. At the end of 2019, there were 330 thousand such people. $82 \%$ of registered self-employed had no official income from entrepreneurial activity, and $42 \%$ of self-employed had no official income at all in the year before tax registration.

More than $20 \%$ of all employed people work in the informal sector, the Federal State Statistics Service estimated. About 13 million employees are invisible to the tax authorities, the NKR rating agency calculated at the end of 2019. Some of them are self-employed. The average age of the self-employed is $30-40$ years, with 6,500 ( $0.6 \%$ of the total) under 18 years of age. Mostly self-employed (do not have an employer and employees) drive taxis, deliver goods, rent apartments, are engaged in tutoring, repair, marketing or offer IT services, follows from the data of the Federal Tax Service. Young people (up to 30 years old), as a rule, work in IT, self-employed people aged 40-50 rent out their housing. Entrepreneurs without hired workers, whose income does not exceed 200 thousand rubles per month (or 2.4 million rubles per year) can become self-employed. Self-employed pay only $4 \%$ for services to individuals and $6 \%$ when working with companies instead of the standard income tax (PIT) of $13 \%$. The self-employed have withdrawn from the shadow more than 130 billion rubles income and paid 3.5 billion rubles. taxes for the entire period of the experiment since January 2019, the Federal Tax Service (FTS) told RBC. Now a special regime for the self-employed operates in 79 of 85 Russian regions [16].

Thus, statistics on the magnitude of the pandemic impact are different due to the difference between the institutional arrangements used in different countries, but the overall negative trend in employment is obvious.

\section{Conclusions}

The emergence of new professions and employment profiles opens up a spectrum of opportunities for the self-employed. The value of the segment of professional services makes it possible to assess the analysis of the development prospects of such sectors as business services, education, healthcare and culture. Radical changes in society create conditions for the emergence of new liberal professions and independent service companies.

The development of digital platforms is helping to reorganize the labour market and transform employment mechanisms. Employers and workers are increasingly found on the Internet. In recent years, online recruiting services have emerged that connect job seekers (including freelancers) with those looking for performers for a wide variety of tasks.

\section{References}

1. M. Kenney, J. Zysman, The Rise of the Platform Economy, Issues in Science and Technology, 32(3) (2016) http://issues.org/32-3/the-rise-of-the-platform-economy (Last accessed 29.12.2020) 
2. E. A. Avdeeva, T. A. Averina, T. E. Davydova, E. N. Zhutaeva, Automation of Russian Industry as an Indispensable Condition for Sustainable Economic Development in the Digital Environment IOP Conference Series: Materials Science and Engineering. Krasnoyarsk Science and Technology City Hall of the Russian Union of Scientific and Engineering Associations, 42041 (2020)

3. N. Herranz, S. Krasa, A. P. Villamil, Entrepreneurs, legal institutions and firm dynamics. Economic Theory, 63(1), 263-285 (2017) https://doi.org/10.1007/s00199-016-1026-8.

4. S. Kergroach, Industry 4.0: New Challenges and Opportunities for the Labour Market. Foresight and STI Governance, 11(4), 6-8. DOI: 10.17323 / 2500-2597.2017.4.6.8 (2017)

5. T. Hang, B.Yehuda, T. M. B. Hong, Towards Self-Employment: Dynamics of Career Mobility, International Journal of Human Resource Management (2019) DOI: 10.1080 / 09585192.2019.1640267

6. D. Bögenhold, R. Klinglmair, F. Kandutsch, Solo Self-Employment, Human Capital and Hybrid Labour in the Gig Economy. Foresight and STI Governance, 11(4), 23-32 (2017) DOI: 10.17323 / 2500-2597.2017.4.23.32

7. N. J. Beitell, J. W. Alsteth, J. A. Schneer, K. Hutt, A Look at the Dynamics of Personal Growth and Exit from Self-Employment, International Journal of Entrepreneurial Behavior and Research, 25(7), 1452-1470 (2019) https://doi.org/10.1108/IJEBR-042018-0239

8. F. M. Vossen, Self-employment in the US Business Cycle: Decomposition. Small Business Economics (2020). https://doi.org/10.1007/s11187-020-00375-3 (Last accessed 29.12.2020)

9. World employment and social prospects: trends in 2020 https://www.ilo.org/global/research/global-reports/weso/2020/WCMS_734479/lang-en/index.htm (Last accessed 29.12.2020)

10. E. Avdeeva, T. Averina, L. Kochetova, Life Quality and Living Standards in Big Cities under Conditions of High Rise Construction Development In the collection E3S Web of Conferences, D. Safarik, Y. Tabunschikov and V. Murgul (Eds.), 03013 (2018)

11. E. Avdeeva, T. Davydova, O. Belyantseva, T. Makeeva, Factors of Sustainable Development of Energy Technologies in the Formation of Digital Economy, 164, 09045, E3S Web of Conferences (2020). DOI: 10.1051 / e3sconf / 202016409045

12. Official site of Rosstat https://rosstat.gov.ru/bgd/free/B04_03/IssWWW.exe/Stg/d05/76.htm (Last accessed 29.12.2020)

13. Y. Lee, T. Mukoyama, Entry and exit of manufacturing plants over the business cycle. $\begin{array}{lllll}\text { European } & \text { Economic } & \text { Review, } & \text { 77, } & \text { 2015) }\end{array}$ https://doi.org/10.1016/j.euroecorev.2015.03.011.

14. S. A. Barkalov, V. Burkov, P. N. Kurochka, Designing systems of group stimulation in the management of energy complex objects Advances in Intelligent Systems and Computing, V(983), 55-68 (2019)

15. T. Davydova, E. Avdeeva, L. Kochetova, T. Makeeva, Methodological approach to the formation and implementation of the human potential of the region, Proceedings of the Volgograd State University International Scientific Conference "Competitive, Sustainable and Safe Development of the Regional Economy "(CSSDRE 2019), 83, 204-207, Advances in Economics, Business and Management Research (2019). Doi: 10.2991 / cssdre-19.2019.41 
16. https://www.rbc.ru/economics/28/08/2020/5f479f9a9a7947f30cef78b0C (Last accessed 11.01.2021)

17. V. N. Burkov, I. V. Burkova, T. A. Averina, T. V. Nasonova, Proceedings of 2017 10th International Conference Management of Large-Scale System Development, MLSD 8109602 (2017)

18. Official site Eurofound URL: https://www.eurofound.europa.eu/topic/new-forms-ofemployment (Last accessed 11.01.2021)

19. OECD, Unemployment rate (indicator) (2020) doi: 10.1787 / 52570002 -en

20. G. Brunello, M. Langella, Local agglomeration, entrepreneurship and the 2008 recession: evidence from Italian industrial districts. Regional Science and Urban Economics, 58, 104-114 (2016) https://doi.org/10.1016/j.regsciurbeco.2016.03.004

21. L.-P. Beland, O. Fakorede, D. Mikola, "The Short-Term Impact of COVID-19 on SelfEmployed Workers in Canada," GLO 585 Discussion Paper Series, Global Labour Organization (GLO). (2020) 